\title{
PENERAPAN MODEL PROBLEM BASED LEARNING UNTUK MENINGKATKAN KEMAMPUAN BERPIKIR KRITIS DAN SIKAP KERJASAMA DI SEKOLAH DASAR
}

\author{
Yulia Nur Maulida*, Karma Iswata Eka, Cicih Wiarsih \\ PGSD, Universitas Muhammadiyah Purwokerto, Indonesia
}

\begin{tabular}{|c|c|}
\hline Article History & \multirow{6}{*}{$\begin{array}{l}\text { Abstrak } \\
\text { Latar belakang penelitian ini adalah rendahnya kemampuan berpiki } \\
\text { kritis dan sikap kerjasama siswa kelas IV SD Negeri } 3 \text { Karangnanas } \\
\text { Penelitian ini bertujuan untuk meningkatkan kemampuan berpikir kriti } \\
\text { dan sikap kerjasama siswa kelas IV SD Negeri } 3 \text { Karangnanas melalu } \\
\text { model pembelajaran Problem Based Learning. Jenis penelitian yang } \\
\text { digunakan yaitu Penelitian Tindakan Kelas dengan dua siklus. Subjel } \\
\text { penelitian ini adalah siswa kelas IV. Instrumen yang digunakan tes dar } \\
\text { non tes. Data dikumpulkan dengan menggunakan soal evaluasi dar } \\
\text { angket untuk mengetahui peningkatan kemampuan berpikir kritis dar } \\
\text { sikap kerjasama siswa. Hasil dari penelitian ini menunjukkan bahwa } \\
\text { kemampuan berpikir kritis pada siklus I memperoleh skor rata-rata 3, } \\
\text { dengan kriteria cukup baik dan siklus II mengalami peningkatar } \\
\text { memperoleh nilai rata-rata 3,6 dengan kriteria baik. Peningkatan juga } \\
\text { terjadi pada sikap kerjasama siswa yang datanya diambil dari lemba } \\
\text { angket pada setiap siklusnya. Hasil yang diperoleh dari angke } \\
\text { menunjukkan sikap kerjasama pada siklus I memproleh skor rata-rat } \\
\text { 3,20 dengan kriteria baik, kemudian meningkat pada siklus II menjad } \\
\text { 3,63 dengan kriteria sangat baik. Hasil penelitian menunjukkan bahwe } \\
\text { penerapan model Problem Based Learning dapat meningkatkar } \\
\text { kemampuan berpikir kritis dan sikap kerjasama siswa. }\end{array}$} \\
\hline Submitted: July 29, 2019 & \\
\hline Accepted : Feb 19, 2020 & \\
\hline Published : Feb 20, 2020 & \\
\hline Kata Kunci & \\
\hline $\begin{array}{l}\text { Model pembelajaran, } \\
\text { Problem Based Learning, } \\
\text { berpikir kritis. }\end{array}$ & \\
\hline
\end{tabular}

\section{PENDAHULUAN}

Pembelajaran merupakan proses interaksi antar sesama individu. Pernyataan tersebut senada dengan Trianto yang menyatakan bahwa pembelajaran dalam arti sempit diartikan sebagai "Produk interaksi berkelanjutan antara pengembangan dan pengalaman hidup” (Trianto, 2011, p. 17). Pengertian tersebut menjelaskan bahwa pembelajaran merupakan proses belajar mengajar terus menerus yang memberikan ilmu dan pengetahuan yang telah dialami. Keberhasilan dalam pembelajaran dilihat dari kemampuan siswa terutama kemampuan berpikir kritis dapat membantu kelancaran dalam proses pembelajaran.

Berpikir kritis di sekolah dasar sangat diperlukan siswa untuk menghadapi tantangan dan perubahan zaman. Generasi selanjutnya dituntut untuk kritis dalam menyikapi suatu permasalahan, namun faktanya masih banyak di beberapa sekolah yang belum menerapkan siswanya untuk berpikir kritis, salah satunya di sekolah yang akan diteliti. Berdasarkan hasil observasi di SD Negeri 3 Karangnanas, terdapat permasalahan siswa masih sulit untuk berpikir kritis, masih banyak ditemukan dalam pembelajaran siswa mengikuti jawaban yang dilontarkan temannya, belum 
menggunakan ide sendiri dan fakta yang ada. Permasalahan yang seperti ini akan menimbulkan dampak yang kurang baik terhadap siswa.

Permasalahan yang lain dari observasi di SD Negeri 3 Karangnanas adalah hasil belajar khususnya pada ranah afektif. Susanto menyatakan bahwa hasil belajar yaitu perubahan-perubahan yang terjadi pada diri siswa, baik yang menyangkut aspek kognitif, afektif dan psikomotor sebagai hasil kegiatan belajar (Susanto, 2013, p. 5). Pengertian di atas menegaskan bahwa hasil belajar merupakan perubahan yang terjadi setelah melakukan kegiatan belajar mengajar dengan menekankan tiga aspek yaitu kognitif atau berkelompok, afektif dan psikomotor. Aspek afektif ini dibuktikan dengan adanya sebagian besar siswa belum mampu bekerjasama dalam kerja tim dan masih bekerja secara individu, sehingga proses pembelajaran kurang efektif.

Kerjasama sangat diperlukan dalam kegiatan berkelompok. Setiap siswa di dalam kelompok akan saling berinteraksi. Johnson menjelaskan bahwa "kerjasama mampu mengatasi berbagai rintangan, bertindak mandiri dan dengan penuh tanggung jawab, mengandalkan bakat setiap anggota kelompok, mempercayai orang lain, mengeluarkan pendapat, dan mengambil keputusan” (Johnson, 2011, p. 164). Pendapat tersebut menjelaskan bahwa kerjasama tidak hanya mengandalkan satu anggota saja melainkan mengandalkan kemampuan setiap anggota kelompoknya.

Berdasarkan permasalahan di atas, dapat diasumsikan bahwa pembelajaran yang dilakukan belum maksimal. Perlu adanya perbaikan pembelajaran yang tepat untuk meningkatkan kemampuan berpikir kritis dan sikap kerjasama siswa. Solusi untuk meningkatkan masalah tersebut yaitu dengan menggunakan model pembelajaran yang inovatif. Model pembelajaran Problem Based Learning (PBL) adalah model pembelajaran yang di dalam proses pembelajaran menggunakan masalah.

\section{METODE DAN FOKUS PENELITIAN}

Penelitian ini adalah penelitian tindakan kelas yang dilaksanakan di SD Negeri 3 Karangnanas terletak di Desa Karangnanas Kecamatan Sokaraja Kabupaten Banyumas. Objek penelitian ini adalah kemampuan berpikir kritis dan sikap kerjasama siswa. Subjek penelitian ini adalah Siswa kelas IV SDN 3 Karangnanas tahun ajaran 2018/2019. Siswa kelas IV berjumlah 27 yang terdiri dari 9 siswa laki-laki dan 18 siswa perempuan. Teknik yang digunakan dalam pengumpulan data ada dua yaitu teknik tes dan non tes. Tes digunakan untuk mengukur kemampuan berpikir kritis dan sikap kerjasama diukur menggunakan angket.

\section{HASIL DAN PEMBAHASAN}

Peneliti menggunakan dua siklus untuk mencapai tujuan penelitian. Setiap dilaksanakan 2 kali pertemuan dengan menggunakan model Problem Based Learning dalam pembelajaran tematik bertema "8 Daerah Tempat Tinggalku". Berikut merupakan histogram perbandingan kemampuan berpikir kritis kelas IV SD Negeri 3 Karangnanas siklus I dan siklus II. 


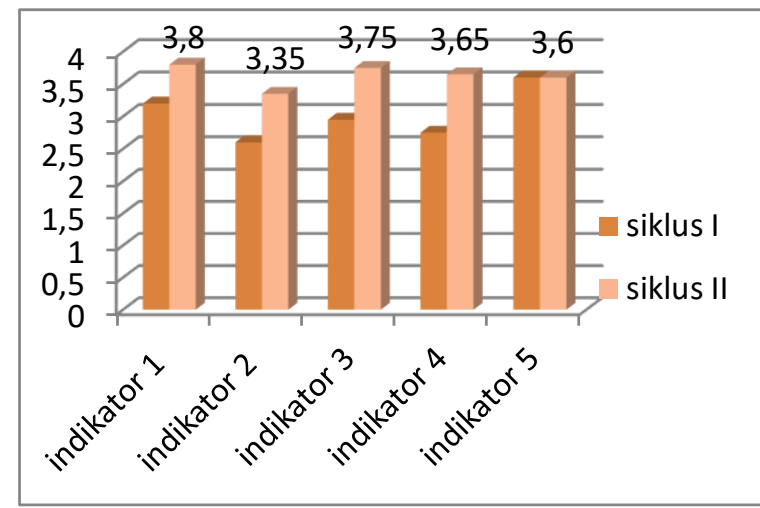

Gambar 1. Perbandingan skor rata-rata kemampuan berpikir kritis tiap indikator

Kemampuan berpikir kritis siswa tiap indikator dapat dijelaskan bahwa pada siklus I dengan indikator 1 yaitu memberikan penjelasan lanjut memperoleh skor ratarata 3,2 dengan kriteria baik, dan siklus II diperoleh skor rata-rata 3,8 dengan kriteria sangat baik. Hal ini menunjukkan adanya peningkatan skor rata-rata dari siklus I ke siklus II yaitu o,6. Indikator 2 yaitu membangun keterampilan dasar pada siklus I memperoleh skor rata-rata 2,6 dengan kriteria kurang baik dan siklus II diperoleh skor rata-rata 3,35 dengan kriteria baik. Hal ini menunjukkan bahwa adanya peningkatan skor rata-rata dari siklus I ke siklus II yaitu sebesar 0,75. Peningkatan ini disebabkan oleh adanya semangat dan pemahaman materi yang diberikan guru pada proses pembelajaran.

Indikator 3 yaitu membuat intervensi/menyimpulkan pada siklus I memperoleh skor rata-rata 2,95 dengan kriteria cukup baik dan siklus II diperoleh skor rata-rata 3.75 dengan kriteria baik. Indikator 4 yaitu memberikan penjelasan lanjut pada siklus I memperoleh skor rata-rata 2.75 dengan kriteria cukup baik dan siklus II diperoleh skor rata-rata 3.65 dengan kriteria baik. Indikator 5 yaitu mengatur strategi dan taktik pada siklus I memperoleh skor rata-rata 3,6 dengan kriteria baik dan siklus II memperoleh nilai rata-rata sebesar 3,6 dengan kriteria baik.



Gambar 2. Perbandingan skor rata-rata kemampuan berpikir kritis

Berdasarkan gambar di atas, membuktikan bahwa terdapat peningkatan hasil evaluasi kemampuan berpikir kritis siswa dari siklus I ke siklus II. Hasil rata-rata kemampuan berpikir kritis siswa dari siklus I dan siklus II mengalami peningkatan yaitu siklus I sebesar 3,0 tergolong dalam kriteria cukup baik, meningkat pada siklus II 
menjadi 3,6 dan tergolong dalam kriteria baik. Berdasarkan hasil tersebut dapat disimpulkan bahwa kemampuan berpikir kritis siswa meningkat pada setiap siklusnya.

Hasil penelitian ini telah melengkapi dan memperkuat penelitian terdahulu seperti yang dilakukan oleh Dianawati (2017), Sianturi (2018), dan Rohmawatiningsih (2008) yang di atas membuktikan bahwa model pembelajaran Problem Based Learning dapat meningkatkan kemampuan berpikir kritis siswa.

Analisis perbandingan skap kerjasama siswa siklus I dan II disajikan dalam gambar 2:

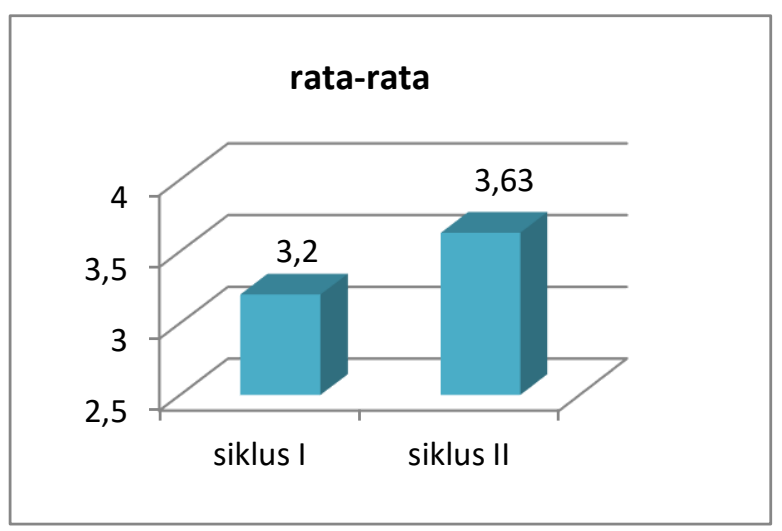

Gambar 3. Perbandingan skor rata-rata sikap kerjasama melalui data angket

Berdasarkan gambar di atas, membuktikan bahwa sikap kerjasama siswa setiap siklusnya mengalami peningkatan. pertemuan siklus I memperoleh skor rata-rata 3,20 dengan kriteria baik. Meningkat pada siklus II memperoleh skor rata-rata 3,63 dengan kriteria sangat baik. Hal ini terjadi peningkatan sikap kerjasama dari siklus I ke siklus II sebesar 0,43.

Hasil observasi yang telah dilakukan di kelas IV SD Negeri 3 Karangnanas dengan kemampuan berpikir kritis siswa awalnya masih memiliki kekurangan. Awal pertemuan siklus I guru belum menyampaikan tujuan pembelajaran, belum menyampaikan pembelajaran dengan baik, kemudian kurang menjelaskan cara mengerjakan yang baik, serta guru belum menjelaskan model pembelajaran yang akan dilaksanakan sehingga pada siklus I pertemuan 1 dan pertemuan 2 guru belum melakukan pembelajaran secara maksimal.

Selesai melaksanakan siklus I, dilakukan refleksi untuk meningkatkan pembelajaran pada siklus berikutnya yaitu siklus II. Terlihat dari kesiapan guru pada awal masuk ke kelas, guru sudah menyiapkan bahan ajar, maupun media yang akan digunakan pada saat proses pembelajaraan. Siklus II guru sudah menguasai langkahlangkah pembelajaran menggunakan model Problem Based Learning. Hal ini terlihat ketika dalam proses pembelajaran guru sudah menyajikan materi dengan sistematis. Guru melakukan tanya jawab kepada siswa yang membuat siswa berpikir lebih luas sesuai dengan apa yang pernah dilihat dan dialami. Sesuai dengan pendapat yang dikemukakan Ennis bahwa berpikir kritis adalah suatu berpikir yang bertujuan dengan membuat keputusan yang masuk akal tentang apa yang diyakini atau dilakukan. Adanya tanya jawab tersebut bertujuan untuk meningkatkan kemampuan berpikir siswa (Susanto, 2016, p. 121). 
Keberhasilan peningkatan hasil belajar berpikir kritis didukung adanya elemen yang membantu dalam proses pembelajaran. Sebelum masuk kelas guru sudah melakukan persiapan seperti menyiapkan model pembelajaran, bahan ajar yang digunakan, dan membimbing proses pembelajaran dengan baik. Hal ini sejalan dengan yang di ungkapkan Joyce dan Weil bahwa model pembelajaran merupakan perencanaan pola untuk pembentukan kurikulum, merancang bahan-bahan pembelajaran, sekaligus membimbing pembelajaran dikelas atau yang lainnya (Rusman, 2014, p. 133). Selama proses pembelajaran guru menggunakan model Problem Based Learning Hal ini dapat meningkatkan keaktifan siswa dalam pembelajaran.

Peningkatan sikap kerjasama merupakan hasil dari kinerja guru yang dilaksanakan pada proses pembelajaran. Guru adalah pelaku utama dalam penyampaian materi yang berdampak terhadap keberhasilan proses pembelajaran. Apabila guru kurang maksimal dalam memberikan penyampaian materi maka siswa akan lebih sulit memahami materi yang disampaikan guru dan begitu juga sebaliknya.

Awal pertemuan siklus I beberapa kelompok masih belum bekerjasama dengan baik. Hal Ini ditunjukkan dengan adanya siswa yang kurang menghargai pendapat teman kelompoknya sehingga membuat siswa enggan berkomunikasi. Sejalan dengan kutipan Johnson yang menyebutkan bahwa belajar dengan kerjasama, yang melebihi cara otak manusia berfungsi, memungkinkan siswa untuk mendengarkan suara anggota kelompok yang lain (Johnson, 2011, pp. 168-169).

Siklus II pada awal pertemuan saat proses pembelajaran berlangsung siswa mulai mampu bekerjasama, berkomunikasi dan membagi tugas dengan baik sehingga siswa dapat menyelesaikan tugasnya dengan tepat waktu. Pernyataan tersebut sesuai dengan pendapat Johnson yang menjelaskan bahwa setiap anggota kelompok saling berhubungan sedemikian rupa sehingga pengetauan yang dimiliki seseorang akan bermanfaat bagi yang lain, output dari satu anggota akan menjadi input bagi yang lain (Johnson, 2011, p. 166).

Pembelajaran yang dilakukan selama dua siklus dengan adanya kegiatan kelompok pada setiap pertemuan menggunakan model Problem Based Learning mengalami peningkatan pada sikap kerjasama siswa. Hal ini sejalan dengan pendapat Wiyani yang menyebutkan bahwa keberhasilan seorang anak ditentukan oleh kemampuan bekerjasama dengan cara sering membuat kerja kelompok pada saat pembelajaran (Wiyani, 2014, p. 77).

Berdasarkan penelitian yang dilaksanakan di SD Negeri 3 Karangnanas terdapat peningkatan kemampuan berpikir kritis dan sikap kerjasama siswa melalui model pembelajaran Problem Based Learning. Keunggulan dari model Problem Based Learning (PBL) yaitu dalam pelaksanaannya siswa menjadi lebih aktif dan antusias dalam mengemukakan pendapat individu maupun kelompok, dan siswa juga bisa bertukar pikiran dengan temannya.

\section{PENUTUP}

Berdasarkan hasil dan pembahasan yang dijelaskan dapat ditarik kesimpulan bahwa Pembelajaran menggunakan model Problem Based Learning dalam pembelajaran tematik bertema "8 Daerah Tempat Tinggalku" dapat meningkatkan kemampuan berpikir kritis siswa. Peningkatan ini terlihat pada hasil evaluasi yang dikerjakan oleh 
siswa yang terus meningkat pada setiap siklusnya. Hal tersebut ditunjukkan dengan hasil tes evaluasi yang diperoleh siswa mengalami peningkatan skor rata-rata yaitu dari siklus I skor rata-rata sebesar 3,0 dengan kritria cukup baik menjadi 3,6 pada siklus II dengan kriteria baik.

Bersamaan dengan meningkatnya proses pembelajaran, terjadi juga peningkatan terhadap sikap kerjasama siswa. Hal ini ditunjukkan dengan adanya data angket yang diisi siswa. Perolehan skor rata-rata pada siklus I sebesar 3,20 dengan kriteria baik, meningkat pada siklus II memperoleh nilai rata-rata sebesar 3,63 dengan kriteria sangat baik.

\section{REFERENSI}

Ajria, N.F, B. Ismanto, F. Kristin. (2018). Peningkatan Kerjasama dan Hasil Belajar Tematik Melalui Model Pembelajaran Problem Based Learning. Jurnal Kajian dan Penelitian Pendidikan dan Pembelajaran, 3(1).

Budi, S.S, E.H. Mulyana, R. Respati (2018). Pengembangan Komik Pembelajaran Subtema Bumi Bagian dari Alam Semesta Pembelajaran Satu untuk Siswa Kelas III Sekolah Dasar. Jurnal Ilmiah Pendidikan Guru Sekolah Dasar, 5(2).

Desmita. (2009). Psikologi Perkembangan. Bandung: PT Remaja Rosdakarya.

Dianawati, N. L. Pt, Pt. N. Riastini, Kt. Pudjawan. (2017). Pengaruh Model Pembelajaran Problem Based Learning terhadap Keterampilan Berpikir Kritis IPA Siswa Kelas V SD No. 1 Ungasan Kecamatan Kuta Selatan Tahun Pelajaran 2016/2017. E-Journal PGSD Universitas Pendidikan Ganesha, 5(2).

Hartono, M dan J. Hartono. (2018). Efektivitas Pengawasan Model Pembelajaran Tematik pada Kurikulum 2013. Jurnal Pendidikan Dasar, 9(1).

Johnson, E. B. (2011). CTL Contextual Teaching E Learning: Menjadikan Kegiatan BelajarMengajar Mengasyikkan dan Bermakna. Bandung: Kaifa.

Rohmawatiningsih, W, I. Rachman, Y. Kodama. (2018). Improving Critical Thinking Skills and Environment Caring Attitude Trough Integrated Environment-Based learning Model. Journal of Sustainable Development Education and Research, 2(1), 69-73.

Rusman. (2014). Model-model Pembelajaran. Jakarta: PT RajaGrafindo Persada.

Sianturi, A, T. N. Sipayung, F. M. A. Simorangkir. (2018). Pengaruh Model Problem Based Learning (PBL) terhadap Kemampuan Berpikir Kritis Matematis Siswa SMPN 5 Sumbul. Jurnal Pendidikan Matematika, 6(1), 29-42.

Suprijono, A. (2014). Cooperative Learning Teori \& Aplikasi PAIKEM. Yogyakarta: Pustaka Pelajar.

Susanto, A. (2013). Teori Belajar Pembelajaran di Sekolah Dasar. Jakarta: Kencana Prenada Media Group.

Trianto. (2011). Desain Pengembangan Pembelajaran Tematik. Jakarta: Kencana Prenada Media Group.

Wiyani, N. A. (2014). Membumikan pendidikan Karakter di SD. Yogyakarta: Ar-Ruzz Media. 